
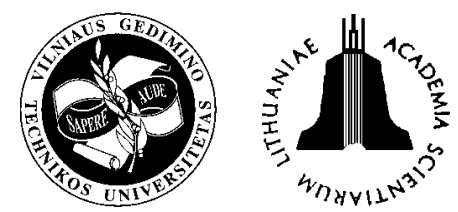

\title{
WORLD TENDENCES OF CIVIL AVIATION DEVELOPMENT AND THE ENLARGEMENT OF THE LITHUANIAN CIVIL AVIATION
}

\author{
Jonas Butkevičius 1 , Aldona Jarašūnienè2 \\ Department of Transport Management, \\ Vilnius Gediminas Technical University, Plytinès g. 27, LT-10105 Vilnius, \\ Lithuania.E-mail:1 ${ }^{1}$ vladas@ti.vtu.lt, ${ }^{2}$ aldonaj@ti.vtu.lt
}

Received 12 December 2005, accepted 28 March 2006

\begin{abstract}
The article deals with global trends in civil aviation, such as: liberalisation of aviation market, globalisation of airlines, privatisation of airlines and invasion of low cost airlines into the market. Also the influence of these trends on the Lithuanian civil aviation activities has been defined.

The Lithuanian civil aviation activities have been analysed: activities of international airports, passenger and cargo carriers, passenger routes and passenger flows, transportation market and airplane fleet. The problems of the Lithuanian civil aviation activities have been identified and suggestions for the development of the Lithuanian civil aviation activities have been proposed.
\end{abstract}

Keywords: civil aviation, airlines, airplane, airport, terminal, passenger flow, cargo, development, liberalisation, globalisation, and privatisation.

\section{Introduction}

Civil aviation plays an important role in the development of the world economy. 1,6 milliard of passengers are carried by air transport yearly. For 2010 the flow of 2,5 milliard of passengers is forecasted in regular flights. It is prognosticated that in 2010 the turnover in air transport sector will reach 1800 milliard of USD [1]. About 1,3 million of people work in the European air transport sector, and approximately $1 \%$ of GDP of the European Union is generated by this sector. In 2015, in European air transport passenger flows are forecasted to make 1,1 milliard of people.

Therefore it is very important to analyse the global trends of civil aviation and to foresee the directions of the Lithuanian civil aviation [1-4].

\section{Civil aviation development trends}

\section{Liberalisation of aviation market}

A principal reason for the liberalisation of aviation market was the competitive struggle of airlines. Governments of many countries tolerated economic regulation long before they little by little resigned from the interference of administrative institutions, and thus the market became more liberal. Users influenced this process as well.
The process of liberalisation of air transport in Europe started during the adjustment of legal acts regulating this field of activity. The European Community's legal measures, which consequently enforced the stages of liberalisation of aviation market, are known as liberalisation packages. Totally there have been prepared and implemented three such packages.

The first package was intended for the liberalisation of the domestic market of the European Union and for boosting the competitive capacities of European airlines. The market continued to be regulated within certain limits so that smaller airlines should not be destroyed, because otherwise a remaining monopolist would be able again to dictate his own prices and therefore users would suffer.

The second package liberalised services according to the third and the fourth "traffic rights", and the fifth "traffic right" was conferred with certain reservations. Conditions were defined under which the designation of airlines to certain routes could be limited. Methods of separation of capacities had been designed.

The third package with suggestions on market liberalisation was prepared in the middle of 1991, and adopted by the European Conference of Transport Ministers in 1992. Legal acts of the third package essentially liberalised the EU air transport market. Cer- 
tain remaining restrictions had to be eliminated until 1 April 1997. Secondary legal acts of the EU defined the order of conferring slots in airports, as well as the measures of competition, also relations with non-EU member states and flight management control requirements.

The main advantage of aviation market liberalisation is the expansion of air transport market, the attraction of more airlines and opening of new routes. Also competition diminished costs of air transport services thus causing the increase of passengers.

After liberalisation airlines got equal conditions for competition and no limitations for flights, prices or network routes. Therefore, the struggle for client needs direct competition not only in terms of tariffs, but also of such parameters as flight frequency, convenience of arrival and departure time, passenger service quality and network of routes [5-13].

\section{Globalisation of airlines}

The objective of cost efficiency induced airlines to consolidate into global alliances. The first alliance "Star" appeared only in 1997, and until the end of the year 2000 four more alliances emerged. So the rapid ness of this process is impressive.

Main alliances of airlines are the following:

- "Star" alliance, uniting "United Airlines" (USA), "Lufthansa" (Germany), "SAS" (Scandinavia), "Air Canada" (Canada), "Thai Airways" (Thailand), "ACE Nippon Airways" and "ANA" (Japan), "Air New Zealand" (New Zealand), "Mexicana" (Mexico), "LOT" (Poland), "Austrian Airlines" (Austria), "Singapore Airlines" (Singapore) and "British Midland Int" (United Kingdom);

- the second largest alliance is "One World" (established in 1998), it comprises "American Airlines" (USA), "British Airways" (United Kingdom), "Qantas" (Australia), "Iberia" (Spain), etc.;

- "SKY Team" alliance includes "Delta" (USA), "Sabena" (Belgium), "Turkish Airlines" (Turkey), "TAP" (Portugal), "Austrian Airlines" (Austria), "Aeromexico" (Mexico) and "Aero Peru" (Peru);

- "Wings" alliance comprises "Northwest" (USA), "Continental" (USA), "KLM" (Holland), "Alitalia" (Italy), "Braathens" (Norway), "Kenya Airways" (Kenya), "American West" (USA) and "Aces Colombia" (Colombia).

Airlines of these alliances get the proportion of about $60 \%$ passengers and they carry more than milliard passengers yearly.

The Lithuanian airline company "Lietuvos avialinijos" - further referred to as "Lithuanian Airlines" or LAL - cooperates with members of "Wings" and "One World" alliances, namely with "KLM Royal Dutch Airlines", "Finnair", "LOT Polish Airlines", "Iberia" airlines. Growing competition of airlines may cause the integration of "Lithuanian Airlines" (LAL) to become an integrated member of any of these alliances.

\section{Privatisation of airlines}

The below methods are most widely applied in the global practice of airlines privatisation:

a) Financial investor.

It is best when a company is able to develop and implement the strategy by its own efforts. In such case the company's long-term strategy, business plans for various kinds of activities, calculated investments are created.

b) Financial investor + strategic partner (a nonshareholder airline company not purchasing shares).

The aim of attracting a strategic partner (airlines) is to benefit from the cooperation, however, the financial investor, as in the prior case, provides financing for necessary implementation of programmes related to the implementation of strategic partnership.

c) Financial investor + strategic partner (a shareholder airline company purchasing shares).

In this case a strategic partner shares the financial risk with a financial investor, and the latter is more apt to invest while knowing that the strategic partner is interested in the development of the company and in profit seeking. However, in the case when the aim of a strategic partner is to benefit from the acquired airlines market positions by using them for this own good, the profit indices usually are not guaranteed.

d) Strategic partner (airline being an investor).

The main disadvantage is that the main company is exploited for solving principal problems, if the problems occur in the main company.

Approximately $80 \%$ of 200 most significant world airline companies have been already privatised.

\section{Low cost companies coming to the market}

The USA Company "Southwest Airlines" is a pioneer of such activities. It delivers services from its own activity centre Love Field and from the secondary airports in Dallas and Texas. It started activities in the end of the year 1970 when the State regulation in the air transport market was cancelled in the USA. At present the "Southwest Airlines" carry 65 million of passengers yearly and it is the most profitable airline company in the USA.

The main activity principles of low cost airlines (including those of the "Southwest Airlines" company) are the following [4]:

- they operate from secondary airports having 
lower runway fees and less expensive ground handling;

- rapid turnover in the airports, for example "Southwest Airlines" has mastered a 25 minute lasting turnover required for the airplane landing, passengers' disembarking, refuelling, embarking new passengers and taking-off again;

- standard airplane fleet - airplanes only of one type are operated ("Southwest Airlines" use only Boeing 737), besides, there are more sitting accommodations - seats;

- ticketing is performed through direct channels (internet, telephone-call centres); therefore there are no reservation fees and no commission for travel agents. The money for unused tickets is irretrievable and reimbursed;

- only economy class services are offered, food is served for additional payment;

- direct flights have no changes for other flights, no local flights.

All the above conditions reduce the costs of such airlines by $40-65 \%$ less than those of traditional airlines.

Currently low cost airlines make $24 \%$ of flights within Europe; they deliver service for 900 routes linking more than 200 towns. They owe more than 250 airplanes, carry almost 60 million of passengers yearly (i. e. $16 \%$ of passengers within Europe).

Low cost airlines have clustered into the ELFAA - the association of low cost airlines. It comprises "Air Berlin" and "Hapag-Lloyd Express" (Germany), "Air Polonia" (Poland), "Flybye" (United Kingdom), "Rynair" (Ireland), "Sverige Flyg" (Sweden), "Sky Europe" (Slovakia), "Sterling" (Denmark), "Transavia/Basiqair" (Holland), "Volareweb" (Italy) and "Wizz Air" (Hungary). The association forecasts that in 2010 the proportions of low cost trips by air transport in Europe will reach $40 \%$ [4].

\section{Analysis of the activities of the Lithuanian civil aviation}

\subsection{International airports}

There are 3 international airports in Lithuania Vilnius, Kaunas and Palanga airports. The airport of Siauliai was assigned to military purposes in 2004 and now it is not used for civil purposes.

It should be noticed that quantities of passengers in the Lithuanian airports are constantly growing. In 1995205,7 thousand of passengers (181,2 thousand by regular flights) arrived and 215,5 thousand (of them 193,0 thousand by regular flights) departed. In 2000 287,3 thousand of passengers (252,1 thousand of them by regular flights) arrived and 294,8 thousand (258,2 thousand by regular flights) departed. In 2004 345,9 thousand of passengers $(294,8$ thousand by regular flights) arrived and 300,8 thousand (292,3 thousand by regular flights) departed.

\section{Vilnius international airport}

It is the main representative airport of Lithuania. The capacity of the airport is about 700 passengers per hour. The airport is capable to serve 1,5 million of passengers per year. During the latter several years Vilnius airport has delivered services to approximately $90 \%$ of all passengers of the Lithuanian air transport (accordingly in $2004-91 \%$ ).

Passenger flows in Vilnius airport are increasing rapidly: 230 thousand of passengers were served in 1993, accordingly 400,9 thousand in 1997, 521 thousand in 2000, and 994,2 thousand of passengers in 2004.

The operation of Vilnius international airport encounters two main problems. The first one is that the Airport has no terminal for handling passengers from non-Schengen countries. Another problem is short length of the runway $(2500 \mathrm{~m})$ for which reason the airport is not able to handle large tonnage airplanes.

\section{Kaunas international airport}

The operation of Kaunas international airport started in 1988. The airport is situated in Karmellava settlement, which is close to Kaunas. The airport area is $500 \mathrm{ha}$; the runway is $3250 \mathrm{~m}$ in length. The airport is capable to handle 500 thousand of passengers and 20 thousand tons of cargo yearly. It should be noted that passenger and cargo flows in this airport are decreasing: if in $1995-38,0$ thousand of passengers and 10,4 tons of cargo were handled, so in 2003 - only 21,7 thousand of passengers and 6,7 thousand tons of cargo were handled, and in $2004-27,3$ thousand of passengers and 3,6 thousand tons of cargo were handled.

The main activities of Kaunas airport include handling of passengers of former LAL Branch Company "Lietuva" ("Lithuania"), also handling of cargo charter flights. In Kaunas airport operate private cargo operators JSC "Transcargo" and JSC "Aviacinių paslaugų centras" ("Aviation Services Centre"). Main cargo flows go from China and Turkey through Kaunas Airport to Russia.

Kaunas airport is in an advantageous location because it is close to the future Kaunas Free Economic Area. However, as far as now, this Free Economic Area has not been established, therefore the possibilities of Kaunas Airport particularly in the field of cargo carriage are not used. Furthermore, debts of the "Lietuva" Airlines to the airport cause a considerable problem. 


\section{Palanga international airport}

The airport of Palanga is situated in particular vicinity - close to the sea, $7 \mathrm{~km}$ away from Palanga Resort and $28 \mathrm{~km}$ from Klaipèda Seaport. The length is $2000 \mathrm{~m}$. The airport capacity is 200 thousand of passengers and 2 thousand tons of cargo yearly.

Regular flights from the airport are operated by "Lithuanian Airlines" and until 2005 by the airline company "Lietuva" (in the end of 2005 after the company went bankrupt its flights were taken over by "Danų oro transportas" - "Danish Air Transport". Besides regional companies from abroad "Swedline" and "Direcflyg" operate here. There are direct flights from the airport to Hamburg, Oslo, Belund, Stockholm, Kristianstadt, Ronneby and Malmõ.

In 1994 Palanga airport handled 17,8 thousand of passengers, in 1997 - already 33,6 thousand of passengers, in 2000 - 39,3 thousand of passengers, in $2003-46,7$ thousand of passengers, and in $2004-76,2$ thousand of passengers.

The main problem of Palanga International Airport is that different passing channels for the EU and non-EU citizens are not implemented in the airport.

\subsection{Passenger and cargo carriers}

The main Lithuanian carriers are the airline companies "Lithuanian Airlines" and "Lietuva" (as mentioned above, at present "Danų oro transportas""Danish Air Transport"). Besides the airlines "Apatas", "Aviavilsa", "Klaipèdos avialinijos", "Transviabaltika”, "Aurela", "Joanos avialinijos", "Gintarinès avialinijos" and "Aviapaslauga" are operating regular or charter flights.

The "Lithuanian Airlines" company was founded in 1991 on the basis of the former "Aeroflot". The company operated as a national airline company, but in 2005 it was privatised. LAL ("Lithuanian Airlines") carries passengers by regular as well as by charter flights. It carries the main passenger flows in Lithuania, furthermore, the proportions of passengers are constantly growing: in 1998 LAL carried 251,6 thousand of passengers, in 2000 - 294,9 thousand of passengers, in 2002 - 304,0 thousand of passengers, and in 2004 994,3 thousand of passengers (from the amount 480,3 thousand by regular flights).

When Lithuania joined the European Union LAL ("Lithuanian Airlines") had to change the strategy of activities, because in the EU area the system of bilateral agreements on air transportation is not functioning any longer and the model of national carrier does not apply LAL ("Lithuanian Airlines"). Actually due to the bilateral agreements on air transport the model guaranteed the success of airline activities. However, after joining the EU, the success of airline activities can rely only on efficient operation of the company.
The airline company "Lietuva" was a branch company of LAL ("Lithuanian Airlines"). It used to carry passengers by regular charter flights. The proportion of passengers of "Lietuva" did not much fluctuate every year: in 1998 it carried 45,6 thousand of passengers, in 2000 - 45,2 thousand of passengers, in $2002-$ 46,2 thousand of passengers, and in 2004-27,3 thousand of passengers.

"Apatas" carries cargo from Kaunas to Malmõ, Riga, Warsaw and Minsk. "Aviavilsa" carries cargo of JSC “DHL International Lietuva”. "Aurela" carries passengers of travel agencies by charter flights. "Klaipèdos avialinijos" makes charter flights to Gdansk, Stockholm, Gothland and Bornholm Islands and to Southern Sweden.

\subsection{Passenger routes and passenger flows}

Initially, when the main passenger carrier "Lithuanian Airlines" was founded, the routes were oriented towards the East, e.g. in 1991, in the Eastern direction 1848 thousand of passengers were carried and only 32 thousand of passengers were carried in the Western direction. In 1993 the geography of flights changed cardinally - flights mainly in the Western direction were started: to London, Copenhagen, Amsterdam, Paris, Berlin, Prague, Frankfurt am Main, etc.

Currently LAL ("Lithuanian Airlines") carry passengers to London, Copenhagen, Amsterdam, Paris, Berlin, Frankfurt am Main, Moscow, SanktPeterburg.

"Lietuva" (present "Danų oro transportas") makes regular passenger flights to Hamburg, Oslo, Belund, Malmõ.

In 2000 LAL ("Lithuanian Airlines") carried most passengers between Vilnius and London - 47,1 thousand and between Vilnius and Amsterdam - 34,5 thousand of passengers.

Passengers from Lithuania by charter flights are carried to Grand Canaria, Tenerrife, Palma de Mallorca (Spain), Hurghada, Charm all Sheich (Egypt), Monostire (Tunis), Antalia (Turkey), Larnaka (Cyprus) and Tel Aviv (Israel). In 1995 passenger flows by charter flights made $11,2 \%$ of all passengers carried by the air transport, accordingly in $2000-12,2 \%$, and in $2004-16,6 \%$.

\subsection{Transport market}

In 1997 flights to Lithuania, apart from LAL ("Lithuanian Airlines") and "Lietuva" airline companies were made by 9 more airline companies and the market of regular flights proportioned in the following way: LAL ("Lithuanian Airlines") $45 \%$, "Lietuva" $8 \%$, SAS - $14 \%$, "Lufthansa" - $11 \%$, LOT and "Estonian Airlines" - $4 \%$ each, "Finnair", "Austrian 
Airlines" and "Aeroflot" - $3 \%$ each, other $-6 \%$.

In 2004 LAL ("Lithuanian Airlines") together with "Lietuva" carried out 40,25\% regular flights, "Air Baltic" - 13,05 \%, SAS - 8,38 \%, LOT - 4,11\%, "Czech Air" - 3,87 \%, "Lufthansa" - 3,85 \%, "Austrian Airlines" - 3,09\%, "Estonian Air" - 1,95\%, "Finnair" - 1,36\%, "Aeroflot" - 0,41\%, other $19,68 \%$.

The market was invaded by a low cost airline company "Air Baltic", which in 2004 carried out even $13,05 \%$ of all regular flights. Therefore the market proportion of LAL ("Lithuanian Airlines"), SAS and "Lufthansa decreased.

"Lithuania airlines" have a largest part of regular flights, but it is shrinking every year.

\subsection{Airplane fleet}

Since the restoration of independence the airplane fleet of airline companies has changed significantly. In 1991 LAL ("Lithuanian Airlines") had 9 Soviet TU 134 and 12 JAK 42 airplanes and finally rented one Boeing 737-200 airplane.

At present LAL has two Boeing 737-200 airplanes, three Boeing 737-500 and three SAAB 2000; "Danu oro transportas" - five ATR 42-300 (three of them belonged to "Lietuva"); "Aurela" - one Boeing 737-200 and one JAK 42; "Aviapaslauga" - one TU 204; "Aviavilsa" - two AN 26B; "Klaipedos avialinijos" - four AN 2, one KA 26, one Piper 140-28 and one P68 Victor; "Apatas" - three L 410WPE, one 410 UVP, one Cessna 421 and one Lear Jet 55.

The airplane fleet of the Lithuanian airline companies is not new, rather oldish and it is not optimal in terms of size or noise emission.

\section{Problems of the Lithuanian civil aviation activities}

The authors' research showed that the main problems of Lithuanian civil aviation are the following:

1. Undefined activity trends of international airports in Lithuania, unidentified validity of construction of a new airport between Vilnius and Kaunas.

2. Terminals of international airports of Lithuania do not meet the requirements of Schengen and the EU. After the liberalisation of aviation market in the European Union and since Lithuania joined the EU, the system of bilateral agreements on the air transport ceased to exist. Therefore a former model of national carrier does not apply to "Lithuanian Airlines" any longer and this requires changing of the strategy of activities.

3. Airports insufficiently cooperate with airline companies in terms of attracting new airlines or developing the flight geography of already existing airlines.

4. Insufficient marketing of our airlines and un- satisfactory cooperation with travel agencies of other countries.

5. The airplane fleet is not optimal in terms of size and noise emission.

6. The runway of Vilnius international airport is not adjusted to service delivery for large tonnage planes.

7. A missed opportunity of privatising the air transport carriers had a negative impact on the results of activities. Privatisation of LAL ("Lithuanian Airlines") did not bring positive results as far as now, and "Lietuva" bankrupted in the end of 2005.

8. Protectionist policy was carried towards the "Lithuanian Airlines" and "Lietuva" companies in respect of Vilnius and Kaunas airports. Therefore after the privatisation of the first company and the bankrupt of the second one considerable debts to the above airports have accumulated thus impeding their development.

\section{Advices concerning the development of the Lithuanian civil aviation activities}

1. Vilnius international airport should be the main airport of the country. It should be oriented towards the services of regular flights and charter flights.

Kaunas international airport should be oriented towards passenger services of low cost airlines and, with the development of Kaunas Free Economic Area, towards cargo handling, and partially to handling charter flights as well.

Palanga international airport should be more oriented towards the passenger services delivery in the directions of Scandinavia and Northern Germany.

2. The construction of a new terminal for handling passengers from non-Schengen countries should be a considerable factor not only for the development of Vilnius international airport, but for the development of the entire civil aviation of Lithuania as well.

3. It is necessary to replace the technology of passenger handling in Palanga international airport by implementing different channels for the EU and nonEU citizens.

4. It is very important to extend the runway of Vilnius international airport from present $2500 \mathrm{~m}$ to $3000 \mathrm{~m}$ length and broaden its side lanes.

5. "Lithuanian Airlines" should change the methods of activities from those of national airlines partially to those of regional ones by changing also the strategy of operation, decreasing operation costs, developing the geography of flights and improving the management.

6 . The extent of flights is a considerable factor of boosting the competitiveness of international airports. 
In this case focus should be put on the development of flight geography.

Currently the most perspective destinations are the following: Sophia (flights operated from Warsaw), Athens (flights operated from Warsaw), Madrid (flights from Warsaw), Roma (flights from Warsaw and Minsk), Lisbon (flights from Warsaw), Bratislava (flights from Warsaw), Zurich and Geneva (flights from Warsaw), Istanbul (flights from Warsaw, Riga and Minsk) and Budapest (flights from Warsaw).

7. The development of charter flights is an important factor of the development of operation of civil aviation of the whole country.

8. It is purposeful to attract a strategic investor for Kaunas international airport. The development of this airport should be related to the development of Kaunas Free Economic Area, also to the implementation of European gauge railway project "Rail Baltica" and the implementation of speed train project between Vilnius and Kaunas.

9. In further perspective it is necessary to introduce intermodal transport technologies in the infrastructure of international airports.

10. Having many users the Lithuanian airline companies should focus on the rapid and efficient analysis of current changes - these purposes should serve an efficient airlines marketing information system and its data-base that would enable efficient decision-making in marketing and should individualise the quality of passenger services $[5,6]$.

11. There exist many factors limiting the formation of airplane fleet meeting optimum demands of enterprises. Such factors are: existing financial state of airline companies, obstacles occurring on the way of reaching considerable financial resources, and the shaped existing fleet, as well as agreements signed [6].

\section{Conclusions}

1. Global development trends of civil aviation are the following: liberalisation of aviation market, globalisation of airline companies, privatisation of airline companies and low cost airlines invading the market.

2. In 1997, in the EU all restrictions concerning the local market access (cabotage) were eliminated, thus the air transport markets of the EU countries were fully liberalised. When Lithuania joined the EU its air transport market opened to all EU carriers.

3. Cost efficiency issues stimulated airline companies to associate into global alliances, the most considerable of which are: "Star", "One World" and "Wings". "Lithuanian Airlines" cooperates only with two latter alliances, not belonging however to any of them.
4. Approximately $80 \%$ of most significant airline companies have been privatised already, including the "Lithuanian Airlines" as well. However the privatisation was accomplished too late. Furthermore, in the end of 2005 the second biggest Lithuanian airline company "Lietuva" bankrupted.

5. Since 1993 the aviation market was invaded by low cost airline companies, which currently account for $24 \%$ domestic regular flights, and deliver services to 900 routes linking more than 200 towns, and carry almost 60 million passengers yearly (about $16 \%$ of European domestic passengers). Low cost airline company "Baltic Air" makes already 13,05\% of all regular flights from Vilnius international airport.

6. Proportions of passengers in Lithuanian air transport constantly grow - if in 1995 Lithuanian airports handled/delivered services to 421,2 thousand of passengers, so in 2004 the proportion reached 546,7 thousand of passengers.

7. The market proportion of "Lithuanian Airlines" still remains the largest one in the regular flights market of Vilnius international airport. However every year it decreases - if in 1997 LAL ("Lithuanian Airlines") itself kept $45 \%$ of market, so in 2004 already only $40,25 \%$ remained (and yet together with the branch airline company "Lietuva").

8. A unique system of three international airports occurred in Lithuania, i. e.: Vilnius, Kaunas and Palanga international airports. It is important that these airports should not compete among themselves, but coordinate their activities in the view of general interests of the country and society.

9. The construction of a new terminal for handling passengers from non-Schengen countries is an important issue of Vilnius international airport.

10. "Lithuanian Airlines" should change their model of activities/operation from the model of a national airline company to that of partially regional airline company, thus changing operation costs, expanding/developing flight geography, cutting management input $/$ costs.

11. It is important to expand the geography of flights from Lithuania. Most perspective directions are those to Sophia, Athens, Madrid, Roma, Lisbon, Bratislava, Zurich, Geneva, Istanbul and Budapest.

12. In the future perspective it is necessary to adjust the infrastructure of Lithuanian international airports for the use of intermodal transport technologies. 


\section{References}

1. Activity of commercial aviation in liberalize market. Research study "Economic study and research". Vilnius, 2005, p. 6-9 (in Lithuanian).

2. Butkevičius, J. The passenger transportation (Keleiviu vežimai). Vilnius: Technika, 2002, p. 348-393 (in Lithuanian).

3. White book. Europe transport policy for 2010 years. Europe Commissions. Brussels, 2001.

4. Liberalisation of Europe air transport. European low Fares Airline Association (ELFAA). Brussels, 2004.

5. EU energy and transport in figures. Statistical pocket book. 2004.

6. Future Lithuanian the word context: experts'. View: a collective monograph. Vilnius: Mokslo aidai, 2003. $416 \mathrm{p}$.

7. Analysis of the European air transport industry 2004. Final report July 2005. 06 Energy and Transport.

8. Aviation and maritime statistics in the candidate countries. Luxemburg: Office for Official Publications of the European Communities, 2004.

9. Chang, Y. European major airlines strategic reaction to the third package. Transport Policy, 2002, No 9, p. $129-142$.

10. Study into the potential impact of changes in technology on the development of air transport in the UK. Final Report to Department of the Environment, Transport and Regions (DETR). 2004.

11. Butkevičius, J. The research into development of passenger transport by land. Transport, Vol XIX, No 5. Vilnius: Technika, 2004, p. 195-201.

12. The economic benefits of air transport. 2004 edition. Air Action Group. Internet: http://www.atag.org

13. The Airbus Global Market Forecast 2003-2022. Internet: http://www.airbus.com 